\title{
COVID-19 Pandemi Sürecinin Merkezinde Ebeler, Ebelerin Merkezinde Kadınlar
}

\author{
Gözde FIRAT ${ }^{1 *}$, Handan GÜLER ${ }^{2}$
}

${ }^{1}$ Sivas Cumhuriyet Üniversitesi Sağlık Bilimleri Enstitüsü Ebelik Anabilim Dalı, Sivas, Türkiye ${ }^{2}$ Sivas Cumhuriyet Üniversitesi Sağlık Hizmetleri Meslek Yüksekokulu, Sivas, Türkiye

$\begin{array}{ccc}\text { Geliş Tarihi } & \text { Kabul Tarihi } & \text { Yayın Tarihi } \\ 12.07 .2021 & 01.11 .2021 & 31.12 .2021\end{array}$

Özet: Covid-19 pandemisi bütün dünyada büyük değişimlere neden olmuştur. Pandemi sürecinde kadın sağlı̆̆ı daha da önemli bir hale gelmiştir. Sadece fiziksel olarak değil ruhsal ve sosyal olarak da tam bir iyilik halini içeren kadın sağlığı; doğum öncesi, doğum, doğum sonu, cinsel ve üreme sağlı̆ının risklerini de içinde barındırır. Pandemi döneminde Covid-19 enfeksiyonuna bağlı nedenlerle; birçok kadının, gebenin, doğum eyleminde olan ve doğum yapan annenin stresörlerinin arttığı görülmektedir. Her süreçte kadınların yanında olan ebeler bu süreçte de görevlerini tüm zorluklara rağmen sürdürmektedirler. Bu derlemenin amacı pandemi sürecinin getirdiği zorlukların kadının yaşamsal süreçlerine etkileri ile artan iş yüküne bağlı ebelerin yaşadıkları güçlükleri ortaya koymaya çalışmaktır. Tüm dönemlerde olduğu gibi ebelik mesleğinin bu süreçte de güçlendirilmesi güçlü ve sağlıklı bir toplum için oldukça önemlidir. Ebeler gerekli izlem ve takiplerle kadınların problemlerini erken dönemde saptayarak erken tedaviyi ve iyileşmeyi sağlayacaklardır. Bu yaklaşım daha güçlü ve sağlıklı kadınlar sağlayarak daha güçlü aile ve toplumların oluşumuna katkı verecektir.

Anahtar kelimeler: Covid-19, kadın sağlığı, doğum öncesi, doğum, doğum sonrası, ebelik

\section{Midwives at the Center of the COVID-19 Pandemic Process, Women at the Center of Midwives}

\begin{abstract}
The Covid-19 pandemic has led to wide alterations all over the world. Women health has become even more critical during the pandemic process. Women health includes not only physical, mental and social health but also includes the risks of prenatal, birth, postpartum, sexual and reproductive health. For reasons related to Covid19 infection during the pandemic period; It is observed that the stressor count of many women, pregnant women and mothers who are in labour and giving birth increase. Midwives, who are with the women in every process, also continue their duties during this pandemic process despite all the difficulties. This review paper aims to reveal the effects of the difficulties brought by the pandemic process on the life of women and the difficulties experienced by midwives due to the increasing workload during the pandemic process. Strengthening the midwifery profession in this process, as in all periods, is very important for a strong and healthy society. Midwives will provide early treatment and recovery by detecting the problems faced by women in the early period with the necessary followup. This approach will contribute to the formation of stronger families and societies by providing stronger and healthier women.
\end{abstract}

Keywords: Covid-19, women health, prenatal, birth, postpartum, midwifery.

$\begin{array}{lll}\text { *Sorumlu yazar } & \text { Firat G 0000-0002-0512-8842 } & \text { Güler H 0000-0002-7474-3160 } \\ \text { Gözde FIRAT } & \text { iD } & \\ \text { alkangozdeebe@gmail.com } & & \end{array}$




\section{GİRIS}

Covid-19 salgınının nedeni SARS-CoV-2 virüsüdür. İlk vakalar (nedeni bilinmeyen zatürre vakaları) 31 Aralık 2019'da Çin'in Hubei eyaleti Wuhan şehrinde görüldü. Daha öncesinde insanlarda görülmemiş olan bu yeni tip coronavirüs 5 Ocak 2020'de tanımlandı. Türkiye'de ise 11 Mart 2020'de ilk pozitif vaka belirlendi (Budak ve Korkmaz, 2020; Uğraş Dikmen ve ark., 2020; Velavan ve Meyer, 2020). Basit bir üst solunum yolu enfeksiyonundan ölüme kadar giden ciddi komplikasyonlar içeren hastalığın çeşitli pulmoner ve sistemik belirtileri tanımlandı (Hapshy ve ark., 2021; Türktan ve ark., 2021). Covid-19'un kalıcı olmayan semptomlarının yanı sıra bazı semptomların kalıcı olduğu görülmektedir. Carfî ve ark. (2020), hastalığın geç semptomları belirlemek için Covid-19 pozitif olan hastalar ile tanı konulduktan 60 gün sonra tekrar görüşme yaparak yakınmalarını değerlendirmiştir. Çalışmada hastaların \%12,6'sı semptom bildirmezken, \%53,1'i yorgunluk, \%43,4 nefes darlığı, \%27,3'ü eklem ağrısı, \%21,7 göğüs ağrısı olduğunu belirtmiştir. Nasserie ve ark. (2021), çalışmasında da Covid19 geçiren kişilerin \%73 en az 1 tane kalıcı semptom yaşadığını ifade etmiştir. En sık yaşanan semptomlar ise nefes darlığı, yorgunluk ve uyku bozuklukları olarak bildirilmiștir.

Diğer bireylerden farklı olarak gebe kadınlar solunum patojenlerine daha fazla duyarlıdır. $\mathrm{Bu}$ nedenle solunum yolu enfeksiyonlarına karşı daha savunmasızdırlar. Covid-19 kadın fizyolojisinin bağışıklık tepkisini etkileyerek, kadının ve fetüsün iyilik halini kötüleştirebilir (Liu ve ark., 2020). Zhang ve ark. (2020), üçüncü tremester gebelerde Covid-19 pozitif olan 16 gebe ile Covid-19 negatif olan 45 gebe kadını karşlaştırmıştır. Covid-19 pozitif olan gebelerin $15^{\prime} \mathrm{i}$ hastalığı semptomsuz veya hafif semptomlu geçirirken bir gebe hastalığı ağır semptomlu geçirmiştir. İki grubun da doğum şekli sezaryendir. İki grup arasında intraoperatif kanama ve yenidoğanın doğum ağırlığı, fetal distres, mekonyumlu amniyotik mayi, preterm eylem ve neonatal asfiksi açısından anlaml farkın olmadığı saptanmıştır. Ankara Aktaş ve ark. (2020), Pubmed, MedRxiv ve Google Scholar veri tabanlarını kullanarak, 1 Şubat 2020 ile 25 Mayıs 2020 tarihleri arasındaki dönemi kapsayan kapsamlı literatür araştırmasında gebe kadınların hastaneye başvuru nedenlerinin ateş ve öksürük olduğu belirlenmiştir. $\mathrm{Bu}$ kadınların \%77'si sezaryen ile doğumunu gerçekleştirmiş, dört kadın yoğun bakımda kalmış fakat anne ölümü olmamıştır. Bir yenidoğan ve bir de intrauterin ölüm meydana gelmiştir. Erken dönemde Covid-19'un gebe ve yenidoğanlarda olumsuz bir etkiye neden olmadığı saptanmıştır. Bu çalışmaların aksine Capobianco ve ark. (2020), meta-analiz çalışmasında ise, maternal komplikasyon ve sezaryen doğum tüm vakaların \%45'ini oluştururken, gebelerin yaklaşık \%20'si yoğun bakım servisine alınmıştır. Preterm eylem \%23 iken en sık rastlanan neonatal komplikasyon pnömoni ve respiratuar distres sendromudur. $\mathrm{Bu}$ sonuçlara göre enfekte bireylerde yüksek oranda maternal ve neonatal komplikasyon olduğu saptanmıştır. Başka bir çalışmada da Covid-19 tanısı ile hastaneye yatırılan 598 gebe kadının başvuru sırasında \%54,5'i asemptomatiktir. Hastaneye başvuru sırasında semptomatik olan Covid-19'lu 272 gebenin $\% 16,2$ 'si yoğun bakım ünitesine yatırılmış ve \%8,5'i solunum desteği almıştır. Covid-19 tanısı ile hastaneye yatırllan 458 gebenin 448 'i canlı doğum yaparken 10 gebe ölü doğum yapmıştır (Delahoy ve ark., 2020). London ve arkadaşlarının (2020), çalışmasında ise, Covid19 ile ilgili semptomlarla başvuran ve daha sonra Covid-19 pozitif tanısı alan gebe kadınların, asemptomatik gebe kadınlara göre daha yüksek erken doğum oranı ve solunum desteği ihtiyacının olduğu saptanmıştır.

Şiddetli semptom belirtisi olan gebe kadınların daha önemli göğüs enfeksiyonu geçirdiği düşünüldüğünden daha özellikli bir bakıma gereksinimleri vardır (Begüm ve ark., 2020). Bu bakım hem kadını hem de fetüs ya da yeni doğanı kapsamalıdır. $\quad \mathrm{Bu}$ nedenlerle Covid-19 pandemisinde doğum öncesi, doğum, doğum sonrası ve üreme ve cinsel sağlığın önemi daha fazla artmıştır. Bu derleme, ebelerin; kadınların fiziksel ve ruhsal sağlıklarını korumak için tüm zorluklara rağmen verdikleri mücadeleyi ve 
verebilecekleri hizmetleri tartışmak amacıyla, mevcut literatür taranarak yapılmıştır.

\section{Ebelik, Covid-19 ve doğum öncesi dönem}

Covid-19 süreci bütün dünyada büyük değişimlere neden olmuştur. $\mathrm{Bu}$ değişimler kadınlar, eșleri ve destek sağlayan kişiler, ebeler, ebelik öğrencileri ve diğer sağlık personelleri olmak üzere bütün doğum hizmetlerini etkilemiştir. Ebelik mesleği Covid-19 sürecinde kadının, fetüsün ve yeni doğanın sağlığının yükseltilmesinde daha da önemli hale gelmiştir (Aydın ve ark., 2020). Ebeler; doğum öncesi dönemde kadının bakımının sağlanmasında, gebeliğin seyrinin yakından izlenmesinde, gebelikte ve doğum sürecinde oluşabilecek komplikasyonların önlenmesinde ve oluşan komplikasyonların yönetiminin sağlanmasında önemli sağlık profesyonelleridir (Begüm ve ark., 2020). Pandemi sürecinde özellikle doğum hizmetlerine erişemeyen ve yüksek riskli kadınların gereksinimlerinin nasıl karşılanacağının ve doğum eylemlerini nasıl planladıklarının bireysel olarak dikkatli bir şekilde incelenmesi gerekmektedir. Doğum öncesi hizmetlerden yeteri düzeyde veya hiç yararlanmayan kadınlar anne morbiditesi açısından iki kat daha fazla risk altındadır (Nair ve ark., 2017). Anne ve yeni doğan ölümleri yüksek olan bazı ülkelerde Covid-19 süreci ile birlikte durum daha da kötü bir hal almıștır. Karantinalar, sokağa çıkma yasakları ve Covid19'a yakalanma riskinin artması, kadınların sağlık kuruluşlarına gitmesine kısmen engel olmuştur. Ebelerin tüm çabalarına rağmen, doğum öncesi, doğum, doğum sonrası dönemlerdeki ve üreme çağındaki kadınlarda Covid-19 ile ilişkili ölümlerin artma olasılığı endişe vericidir. $\mathrm{Bu}$ karmaşanın içerisinde yer alan bütün kadınlar ve doğmamış bebekleri fiziksel ve duygusal bir ortamda güvenli ve insancll bir doğumu hak etmektedirler. Bu da güvenli doğum sürecinin ve kaliteli ebelik bakımının ne kadar hayati bir önem taşıdığını göstermektedir. Kadın merkezli bakımı her türlü koșulda sürdürmeye çalışan profesyonel ebeler, pandemi sürecinde de üstlerine düşen görevleri en iyi şeklide üstlenmektedirler (Kimani ve ark., 2020; Pallangyo ve ark., 2020; Brislane ve ark., 2021). Covid-19 salgını sürecinde cinsiyete göre kaygı düzeylerine bakıldığında kadınların erkeklere göre daha yüksek kaygı düzeyinde olduğu saptanırken algılanan stres düzeylerinin orta derecede olduğu belirlenmiştir (Göksu ve Kumcağız, 2020). Gebelerin stres düzeylerinin belirli nedenlere (sosyo-ekonomik ve sosyodemografik özellikler, obstetrik özellikler) bağlı olarak yüksek olduğu saptanmıştır (Sis Çelik ve Atasever, 2020). Gebe kadınların sürece bağlı olarak sosyal destekleri azalmış ve bebeklerinin sağlığına yönelik endişeleri artmıștır (Kitapçığlu ve ark., 2008). Pandemi sürecinde bu endişe ve korku fobiye dönüşmüştür. Covid19 fobisinin gebe olan kadınlarda olmayanlara göre daha yüksek olduğu belirlenmiştir (Karkın ve ark., 2021). Pandemi süreci kadınların hamileliklerini, kendi ve bebeklerine ait seçimlerini, doğum bakımlarına yönelik korkularını etkilemektedir. Bunların yanı sıra gebe kadının yalnız bir şekilde izole olması, anksiyete ve depresyon düzeyini artırabilir (Ataş ve Bay, 2020). Gebe kadınların pandemi sürecinde sosyal destek faktörünün ve ekonomik güçlüklerinin erken dönemde değerlendirilmesi, gerekli girişimlerin zamanında yapılmasını sağlayacağı için ruh sağlığını korunmada önemlidir (Genç Koyuncu ve Palas Karaca, 2021). Du ve arkadaşlarının (2020), doğum öncesi bakım sorunları ve taleplerini değerlendirdikleri 2002 gebe kadın ile yürüttükleri çalışmada gebelerin yaklaşık \%94,6'sı Covid-19 salgını sırasında enfekte olmaktan korkarken, sadece \%14,7'si psikolojik danışma talebinde bulunmuştur. Primiparaların, multiparalara göre online destek almak için daha istekli olduğu saptanmıştır. Gebelerin en çok endişe duyduğu konu ise Covid-19'a karşı kişisel korunmayı nasıl sağlayacağıdır. Bu çalış-mada da görüldüğü gibi ebelerin gebe kadınların bilgi düzeylerini sorgulayarak gereksinimlerini belirlemesi, gerekli bakım, eğitim ve danışmanlıkları sağlaması önemlidir. 
Covid-19 sürecinde ebelerin gebe kadınlarda sorgulamasi gereken bilgiler:

-Gebe kadının öz yeterliliği,

-Önleyici tedbirlere duyarlılığını tetikleyen bilgileri,

-Algllanan tehdide ve sağlı durumuna yönelik farkındalı̆̆

-Sağlık sistemine ulaşma düzeyi.

Gebe kadının öz yeterliliği genel ve özel bakım gereksinimlerini tanımasına bağlıdır. Sosyal ağlarda dolaşan bilgi kirliliğinden dolayı kadınlar doğru bilgiye ulaşmada güçlük yaşayabilir. Ebeler gereken tüm bilgi ve bakımları sağlayarak kadınlarda derin risk algısı ve farkındalık sağlayabilir. Ancak kadınlar aldıkları bilgiler ve bakımlar doğrultusunda kendilerine stres oluşturmadan gerekli önlemleri almalıdır. Sağlık hizmetlerinin ulaşılabilirliği artırılarak gebe kadınların daha fazla hizmetten yararlanması sağlanmalıdır. Ebeler Covid-19 sürecinde doğum öncesi bakımın etkin bir şekilde alınmasını sağlamalı ve riskli ve yüksek riskli gebe kadınları daha fazla sıklıkta izlemelidir. Bu yaklaşım fetal sağlığı yükselterek doğumsal anomalilerin ve fetal ölümlerin oranlarının azalmasına katkı sağlayacak ve anne ölümlerini azaltacaktır (Rezaei ve ark., 2021). Bazı ülkelerin gebe kadının takip ve tedavisini gerçekleştirmek için süreci farklı şekillerde yönettiği görülmektedir. İngiltere'nin bazı bölgelerinde kadınlara tansiyon aleti ve idrar tahlili çubukları verildi ve izlemlerini kendilerinin yapması sağlandı. Hipertansiyonu olan gebe kadınlar kendi izlemlerini bu şekilde sağlayıp sonuçlarını sağlık çalışanlarına bildirdi. İtalya'da bazı klinikler doğum öncesi izlem polikliniklerini azaltarak kadınlarla telefon ile görüşme sağladı ancak yüz yüze ve ev ziyaretlerini de beraberinde sürdürdü. İspanya'da da benzer şekilde gebe kadınlar hem klinikte yüz yüze hem de telefon görüşmeleri şeklinde izlendi (Coxon ve ark., 2020). Türkiye'de ise gebe izlemleri kliniklerde yapılmaktadır. Gebe kadının sağlık kuruluşunda geçirdiği süre mümkün olduğunca kısa tutulmaktadır. Kadınlar rutin izlemleri dışında gereksiz ek izlemler için çağrılmamakta ve randevulu hasta kabulü gerçekleștirilmektedir. Gebe eğitimleri mümkün ise çevrimiçi ortamda yapılmaktadır (SB, Bilimsel Danışma Kurulu Çalışması, 2020). Pflugeisen ve ark. (2016), sanal ziyaretlerin yüz yüze ziyaretler kadar güvenli olduğunu kanıtlamışlardır. Bu durumun aksine Chen ve ark. (2020) özellikle kırsal kesimlerde sanal iletişimin zorluğunu vurgulamıştır. Özellikle acil durumlarda ve yüksek riskli kadınlarda tele sağlık uygulamasından ziyade klinikte muayene ve bakımın daha uygun olduğu belirtilmiştir. Ayrıca dil, anlama sorunu ve/veya zihinsel problemi olan kadınlarla tele iletişimin güç olacağı ve bu kadınların etkin bir şekilde değerlendirilemeyeceği üzerinde durmuştur.

Sanal izlemlerde yüksek riskli gebeliği olan kadınlarda fetal kalp atımına (FKA) bakılamazsa bu durum kaygıyı artırabilir. Ayrıca preeklampsi ve diğer doğum öncesi yaşanan riskli durumların gözden kaçmasına neden olabilir. Kadınlar telefon veya online görüşmelerin yeterli olduğunu düşünebilir ve bu düşünce ile SARSCoV-2 virüsüne bağlı enfeksiyon kapmış olsa bile klinikte ek bakım almaktan mahrum kalabilirler (Coxon ve ark., 2020). Pandemi sürecinde sağlık hizmeti sunan profesyoneller; doğum öncesi süreçte yüksek riskli kadınları yakından takip ederek, yüz yüze görüşmeler sağlamalı ve olası bütün riskleri değerlendirmelidir. Gebelerin gereken bakım ve hizmetleri alması sağlanarak iyilik halinin devamlılı̆̆ı sağlanmalıdır (Esegbona-Adeigbe, 2020). Bütün kadınlar aynı eğitim seviyesine, kültüre ve anlama düzeyine sahip olmadığından dolayı gerekli olan bilgiler verilirken kadının anlayabileceği sade bir dil kullanılmalıdır (Rezaei ve ark., 2021). Ayrıca gebe kadının asemptomatik olması Covid-19 enfeksiyonun gözden kaçmasına neden olabilir. Kliniği asemptomatik olsa dahi Covid-19 pozitif olan gebe kadınların bakımında, iyi bir izlem yapmak önemlidir. Gebe kadın doğum ünitesine kabulü yapılırken Covid-19 yönünden değerlendirilmeli ve pozitif olması durumunda gereken tüm önlemler alınmalıdır. Covid19'unun kadında bulunup bulunmadığının tespiti serviste veya doğum ünitesinde yatan tüm gebeleri, yeni doğanları, doğum 
partnerlerini ve sağllk personellerini korumak için gereklidir (Delahoy ve ark., 2020).

\section{Ebelik, Covid-19, doğum ve doğum sonrası dönem}

Durağan olmayan doğum eylemi pandemi sürecinde de devam etmektedir (RoccaIhenacho ve Alonso, 2020). Covid-19 pandemisinde doğum yapmak kadında korku ve endişenin artmasına neden olmuştur. Çünkü çoğu klinik doğumda doğum partneri kabul etmemiş, kadınların birçoğu klinik ortama ve yapılacak girişimlere yabancı kalmışdır. Ayrıca ebeler tarafından kullanılan koruyucu ekipmanlar gebe ile göz temasını ve yakınlığı engellemiş, araya istenmeyen sosyal mesafe girmiştir. Birçok ülkede enfeksiyon bulaşma korkusundan dolayı kadınlar, kendi sağlığını ve bebeklerinin sağlığını korumak için doğumunu evde veya bağımsız doğum merkezlerinde gerçekleştirmek istemişdir (Monteblanco, 2021). Hollanda'da doğum sırasında Covid-19'u pozitif olsa dahi doğum partnerine (bir kişi olacak şekilde) izin verilmektedir. Fransa'da eșler doğumda bulunabilmekte ancak koruyucu giysiler giymeleri istenmektedir. İspanya'da da bir partnerin bulunması desteklemekte ancak bu kural farklı sağlık merkezlerinde değişiklik gösterebilmektedir (Renfrewa ve ark., 2020). Doğum sürecinde (labor) yetersiz bakım sağlanması, yapılan gereksiz müdahaleler, anne bebeğin ayrılması, emzirmenin yasaklanması, refakat kısıtlaması doğum eyleminde kadın haklarını tehdit eden unsurlardır (RoccaIhenacho ve Alonso, 2020; Brislane ve ark., 2021). Covid-19 pozitif olan gebe kadınlar negatif olanlara göre içerisinde bulundukları süreçten dolayı daha fazla endişe, korku ve anksiyete yaşayabilirler. Yaşanan endişe ve korku kadının doğum eyleminde kendi bakımına katılmasına ve süreç yönetilirken kendi isteklerini ifade etmekte çekimser kalmasına neden olabilir (Bick, 2020). Doğum korkuları nedeniyle kadın sezaryen isteminde bulunabilir (Nur, 2015). Bu da normal doğum sürecini kesintiye uğratarak doğum eyleminin doğallıktan uzaklaşmasına neden olacaktır (Sayıner ve Özerdoğan, 2009). Ebeler kadın merkezli bakımı sürdürmeli ve gebe kadın ile sürekli iletişim halinde olmalıdır. Ayrıca kadını kendi bakımına katmak için çaba sarf etmelidir. Kadınlar bütün süreçlerde olduğu gibi pandemide de istisnasız güvenli doğum hizmeti alma hakkına sahiptir. Verilecek kaliteli bakım kadın, bebek ve doğum partnerinin de içinde bulunduğu bir güven çemberini oluşturur. Covid-19 sürecinde güvenli doğum sağlamak için kadın ve bebeğinin gereken fiziksel ve ruhsal bütün gereksinimleri ebeler tarafından karşılanmalıdır. Ancak ebelerin bunu sağlayabilmesi için güçlü ve sistemli bir sağlık uygulamasına gereksinim vardır (Rocca-Ihenacho ve Alonso, 2020). Sağlık profesyonelleri olan ebeler doğum sürecinde kadınların yeterli bakım almasını sağlamalıdır. Bakım sırasında gerekli önlemler alınarak (yeterli koruyucu ekipman, doğum odasının izolasyon sürecine göre ayarlanması, sadece yeterli düzeyde sağlık personelinin doğum odasında bulunması, vb.) enfeksiyonun yayılması önlenmelidir (Çağlar ve Yeşiltepe Oskay, 2020). Covid-19 sürecinde güvenli doğum kadar doğum sonrası dönem de önemlidir. Ebe doğum sonu ev ziyaretleri ile doğum sonu bakım, emzirme, aile planlaması, hijyen gereksinimi ve yenidoğan bakımı konusunda yeni ebeveyn olan bireylere destek sağlar (Mokhtari ve ark., 2018). Çuvadar ve ark. (2020), Covid-19 sürecinde belirsizlik ve bilinmezlik yaşanması durumunun doğum sonrası dönemde de kadınlarda kaygların artarak devam etmesine neden olduğunu bulmuşlardır. Ayrıca doğum sonrasında annenin bebeğiyle temas kuramaması, emzirmenin engellenmesi, kadınların evde bekleyen başka çocukların varlığı da kadının kaygılarının daha da artmasına neden olmuştur. Ebeler bu süreçte hem bakım uygulamalarını yerine getirmeli hem de psikolojik yönden kadını desteklemelidir. Bunun için eğer mümkün ise kadının uzaktan da olsa bebeğini görmesi sağlanmalı, anne sütü ve sağma ile ilgili eğitim vererek memelerinin uygun saatlerde ve doğru teknik ile boşaltılması gerçekleştirilmeli, enfeksiyon kontrol altına alınarak ve hijyen kurallarına dikkat edilerek annenin kaygıları en aza indirmeye çalışılmalıdır. Zanardo ve ark. (2020) Covid-19 karantina döneminde doğum yapan annelerin 
Covid-19'a maruz kalma riskine ilişkin endişeler yaşadıkları, depresif belirtilerin kötüleșerek ruhsal sağlıklarını olumsuz etkilediğini belirlemiştir. Ceulemans ve arkadaşları (2020), Covid-19 sürecinde majör depresif semptomlarını gebelerde \%25,3 ve emziren annelerde ise \%23,6 olarak saptanmış-tır. Bir başka çalışmada ise depresif belirtilerin yaygınlığı doğum yapan kadınlarda \%44,2 olarak belirlenmiştir (Ostacoli ve ark., 2020).

Yeni ebeveyn olan bazı bireyler, bebeklerini büyütürken sosyal destek arayışlarını online olarak karşılamış, endişe, kaygı ve stres yaşayan ebeveynler resmi ve resmi olmayan kaynaklarla doğru bilgilere ulaşmaya çalışmıştır (Ollivier ve ark., 2021). İçerisinde bulunduğumuz süreçten dolayı doğum sonunda sinırlı sosyal destek olması, sosyal mesafe kuralları ve izolasyon gibi faktörlerden dolayı kadının ruh sağlığına öncelik verilmesi önemlidir. Bebeğin bakımına kadını da dahil etmek annelik rolünün gelişmesine katkı sağlayacaktır. $\mathrm{Bu}$ nedenlerden dolayı ebeler anne ve bebekler için tüm rollerini ve özellikle de savunuculuk rolünü güçlü bir şekilde üstlenerek bakım, eğitim ve danışmanlık hizmetlerini gerçekleștirmelidir (Green ve ark., 2021).

\section{Ebelik, Covid-19 ve kadın sağlığı}

Pandemi süreci; kadınların yetersiz bakım, eğitim ve danıșmanlık hizmeti almalarına neden olabileceğinden, bu süreçte kadının üreme sistemi ve cinsel sağlı̆̆ının da olumsuz etkilenebileceği riski göz ardı edilmemelidir. $\mathrm{Bu}$ süreç kadınların sağlıksız düşükler yapmalarına, güvensiz küretajların gerçekleşmesine ve cinsel sorunların yaşanmasına neden olabilir. $\mathrm{Bu}$ nedenle kadınlar daha riskli bir grubu oluşturdukları için, salgın süreçlerinde özenle ele alınmalıdır (Öztürk Çopur ve Can, 2021). Doğum sonu dönemde ya da üreme çağında olan kadınlara ebeler tarafından cinsel ve üreme sağlığı eğitimleri verilmeli, aile planlaması danışmanlığı yapılmalı ve kadının uygun gördüğü, tıbbi açıdan da ebenin onayladığı doğru yöntemi bulmasına yardımcı olunmalıdır. Belay ve ark. (2020), Covid 19 salgın süreci güvenli kürtaj ve aile planlaması hizmetlerini olumsuz yönde etkilemiş ve verilen bu hizmetler sayıca önemli ölçüde azalmıştır. Başka bir çalışmada ise Covid 19 sürecinde Yogyakarta'da bağımsız ebeler tarafından yürütülen aile planlaması hizmetlerinde \%13,8 oranında azalma olduğu saptanmıştır. Aile planlamasındaki bu düşüşün doğum oranının artmasına neden olabileceği düşünülmektedir (Herawati ve ark., 2020).

Kadın sağlığı için ciddi bir endişe kaynağı olan başka bir konu ise sokağa çıkma yasakları ve karantina süreçleri ile birlikte toplumsal cinsiyete dayalı şiddet vakalarının artmasıdır. Pandemi sürecinin getirdiği zorluklar ile aile içi sorunların birleşmesi stres faktörlerini daha da artırmıştır. Sosyal etkileşimin az olması, şiddet uygulayan kişiler için firsat anlamına gelebilir çünkü aile dışı bireylerin görüp, müdahale etmesi için daha az fırsat vardır (Gausman ve Langer, 2020; Kim, 2020; Mittal ve Singh, 2020; Ünal ve Gülseren, 2020; Demir ve Taşpınar, 2021). Covid-19 önemli bir tehdit oluştursa da kadınların sağlık hizmetine ihtiyaç duymaya devam ettiği bilinmelidir. Bu nedenle etkili aile planlaması, cinsel yolla bulaşan hastalıkların önlenmesi ve kanser taraması gibi bütün hizmetlerden kadınların yararlanabilmesi için tüm olanaklar üst düzeyde kullanılmalıdır. (Carneiro, 2020).

\section{Ebelerin yaşadığı zorluklar}

Ebe; Covid-19 ile mücadelede doğum öncesi, doğum, doğum sonrası bakım, yenidoğan bakımı, üreme sağlığı, aile planlaması ve halk sağlığı çalışmalarının merkezinde olan, bilim ve sanatı harmanlayarak kadını kendi bakımına katılması için teşvik eden kilit insan gücüdür (Ataş ve ark, 2020; Bick, 2020; Coxon ve ark., 2020). Anne ve bebek bakımında birincil rol üstlenen ebeler pandemi sürecinde büyük zorluklar yaşamıştır (Green ve ark., 2021). Ulusal (2021)'n çalışmasında kadın sağlık çalışanlarının; koruyucu ekipmanların giyilmesini, hijyen kurallarına ekstra önem vermeyi ve sosyal mesafeyi koruma çabalarını çalışma koşullarını zorlaştıran durumlar olarak belirttikleri saptanmıştır. Sağlık çalışanlarının ailesiyle olan iletişimini de etkileyen bu süreçte kadın sağlık çalışanları çoğu kez aile bireylerinden kendini soyutlayarak izole yaşamak zorunda kalmıştır. Sağlık sunucularının bu zor koşullar, uzun 
çalışma saatleri ve hak ettikleri maddi ve manevi desteği hissedememeleri, içinde bulundukları süreci daha da karmaşık ve zor hale getirmiştir. Kliniklerde birimler arası değişimler yapmak zorunda kalan veya Covid-19 hastalarına temasta bulunan ebelerin aynı zamanda, doğum sürecinde olan anne ile teması bu kadınlar için de risk oluşturacaktır. Bu nedenle ebelerin kendi meslek alanlarında çalışarak hem kendi iş doyumlarını artırıp hem de gerekli izlemlerin zamanında yapılmasını sağlamaları önemlidir. Ayrıca ebelerin var olan veya oluşabilecek riskli durumları önceden belirlemesi, oluşabilecek komplikasyonları önlenmesi gerekmektedir. Ebelerin gerekli cinsel ve üreme sağlığı hizmetlerini ihtiyacı olan özelde kadına genelde aile ve topluma sunması gerekmektedir. Büyük ekiple çalışan ebelerin bir tane veya az sayıda dinlenme odasının olması ya da hiç olmaması da çapraz bulaşmaya neden olabilecektir. Klinik içerisinde düzenlemeler yaparak enfeksiyon gelişme ve yayılma olasılığı ortadan kaldırılmalıdır (Şahan, 2010; Ataş ve ark, 2020; Rocca-Ihenacho ve Alonso, 2020). Ebeler için hazırlanan pandemi yönetim rehberlerinin uygulamalara yardımcı olması önemlidir. Yeni Zelanda'da sağlık kuruluşlarından gelen Covid19 rehberinin, bakımın sürekliliğini sağlayan ebeler için kişisel strese yol açtığı ve belirsizlikler ortaya çıkardığı görülmüştür (Crowther ve ark., 2021). Pandemi süreci ebelerin kadın merkezli bakım uygulamalarını olumsuz etkilemiştir. Özellikle, savunmasız olan kadınların yüksek risklere maruz kalmasından endişe duyan ebelerin stres ve kaygı düzeyleri artmıştır (Murphy, 2020; Bradfield, 2021). Bu zorlu süreçten ebelik öğrencileri de etkilenmiş ve çoğu öğrenci klinikten uzak kalmıştır. Salgın döneminde, kadın ebelik öğrencilerinin \%5'inin orta veya yüksek düzeyde kaygıya sahip olduğu görülmüştür (Sögüt ve ark., 2021). Başka bir çalışmada ise ebelik bölümü öğrencileri için online eğitim ve arkadaşlarından uzakta olmak öğrenmeyi zorlaştırırken, öğrenciler; koruyucu ekipmanın kendilerine yetersiz sağlanmasından dolayı kendilerini değersiz hissetmişdir. Süreçte; evde olmak, aile sorunları ve maddi problemlerle iç içe olmak ebelik öğrencilerinin duygusal yükünü artırmıştır (Kuliukas ve ark., 2021). Öğrenciler sadece okuldan değil klinik ortamdan, dolayısıyla ebelik mesleğinden de ayrı kalmıştır. Bazı ülkelerde klinikler koruyucu ekipman eksikliği nedeniyle, bazı klinikler ise bilinmezlik nedeni ile kapılarını öğrencilere kapatırken, bazı bölgelerde bu durumun tam aksine sağllk personeli yetersiz olduğundan dolayı hizmet talebini karşılamak için tam zamanlı olarak çalıştırılmışlardır. Pandemi; klinik eğitimin bozulmasına, öğrencilerin bakımın kendileri tarafından nasıl sağlanacağını yeterli derecede öğrenememelerine neden olmuştur. Nitelikli ve donanımlı ebeler olmadan kadınların bakım taleplerinin karşılanması mümkün değildir (Lazenby ve ark., 2020). Bakım hizmetlerinin ön saflarında yer alan ebeler güvenli anneliğin tam anlamıyla sağlanması için her zaman ve her koşulda kadınların ve ailelerin yanında olmuş ve olmaya da devam edecektir (Jolivet ve ark., 2020; Murphy, 2020).

\section{SONUÇ}

Ebelik mesleğinin pendemi sürecinde daha fazla desteklenerek, ebelerin mesleki doyumları artırılmalıdır. Mesleki doyumu artan ebelerin sahada, kadınlara dolasıyla aile ve topluma katkıları şüphesiz artacaktır. Bu süreçte gebe olan ve olmayan kadınların izlemlerine her zamankinden daha fazla titizlikle yaklaşılmalı pandeminin fiziksel ve ruhsal etkileri değerlendirilirken kadınların süreçten olumsuz etkilenmemesi için çalışmalar yapılmalıdır. Kadın merkezli bakım her zaman öncelikli olmalı ebeler mesleki hedeflerinden asla vazgeçmemelidir.

\section{Çıkar Çatışması}

Yazarlara ait herhangi bir çıkar çatışması bulunmamaktadır.

\section{KAYNAKLAR}

Ankara Aktaş H, Aboalhasan Y, Aygün T, Başol G, Kale A (2020) Covid-19 ve gebelik. South. Clin. Ist. Euras 31: 69-73.

Belay L, Hurisa T, Abbas F, Daba M, Abebe B, Nigatu B, Prager $S$ (2020) Effect of covid-19 pandemic on safe abortion and contraceptive services and mitigation measures: a case study from a tertiary facılıty in ethıopıa. EJRH 12(3): 51-56. 
Bradfield Z, Hauck Y, Homer CSE, Sweet L, Wilson AN, Szabo RA, Wynter K, Vasilevski V, Kuliukas L (2021) Midwives' experiences of providing maternity care during the covid-19 pandemic in Australia. Women and Birth 10:1-10.

Brislane A, Larkin F, Jones H, Davenport MH (2021) Access to and quality of healthcare for pregnant and postpartum women during the covid19 pandemic. Frontiers in Global Women's Health 2: 1-10.

Budak F, Korkmaz Ş (2020) Covid-19 pandemi sürecine yönelik genel bir değerlendirme: Türkiye örneği SAYOD (1): 62-79.

Capobianco G, Saderi L, Aliberti S, Mondoni M, Piana A, Dessole F, Dessole M, Cherchi PC, Dessole S, Sotgiu G (2020) Covid-19 in pregnant women: a systematic review and meta-analysis. EJOG 252: $543-$ 558.

Carfî A, Bernabei R, Landi F (2020) Persistent symptoms in patients after acute covid-19. JAMA 324(6):603-605.

Carneiro MM (2020) Women's health during the covid-19 pandemic: new roles and views in health care. Women \& Health 60:8, 849-850.

Ceulemans M, Hompes T, Foulon V (2020) Mental health status of pregnant and breastfeeding women during the covid-19 pandemic: a call for action. JOGI 151(1): 146-147.

Chen H, Guo J, Wang C, Luo F, Yu X, Zhang W, Li J, Zhao D, Xu D, Gong Q, Liao J, Yang H, Hou W, Zhang Y (2020) Clinical characteristics and intrauterine vertical transmission potential of covid-19 infection in nine pregnant women: a retrospective review of medical records. Lancet 395: 809-815.

Crowther S, Maude R, Zhao IY, Bradford B, Gilkison A (2021) New zealand maternity and midwifery services and the covid-19 response: a systematic scoping review. Women and Birth 34(4): 1-40.

Çağlar M, Yeşiltepe Oskay Ü (2020) Covid-19 pandemisi sürecinde gebelik ve doğum yönetimi. SBÜ Hemşirelik Dergisi 2(2): 99-104.

Çuvadar A, Özcan H, Arıkan MG, Ateş S (2020) Covid-19 tanılı gebede postpartum kaygı düzeyi: iki olgu sunumu. Ordu University J Nurs Stud 3(3), 297 30.

Delahoy MJ, Whitaker M, O'Halloran A, Chai SJ, Kirley PD, Alden N, Kawasaki B, Meek J, YouseyHindes K, Anderson EJ, Openo KP, Monroe ML, Ryan PA, Fox K, Kim S, Lynfield R, Siebman S, Davis SS, Sosin DM, Barney G, Muse A, Bennett NM,
Felsen CB, Billing LM, Shiltz J, Sutton M, West N, Schaffner W, Talbot K, George A, Spencer $M$, Ellington S, Galang RR, Gilboa SM, Tong VT, Piasecki A, Brammer L, Fry AM, Hall AJ, Wortham JM, Kim L, Garg S, Covid-Net Surveillance Team (2020) Characteristics and maternal and birth outcomes of hospitalized pregnant women with laboratory-confirmed covid-19 covid-net, 13 states, march 1-august 22, 2020. MMWR Morb Mortal Wkly Rep 69(38): 1347-1354.

Demir R, Taşpınar A (2021) Koronavirüs pandemisinin kadının yaşamına ve sağlığına yansımaları. Psikiyatride Güncel Yaklaşımlar, 13(4): 779-789.

Esegbona-Adeigbe $\mathbf{S}$ (2020) Impact of covid-19 on antenatal care provision. Eur J Midwifer 4(16): 1-2.

Gausman J, Langer A (2020) Sex and gender disparities in the covid-19 pandemic. J Womens Health (Larchmt), 29(4): 465-466.

Göksu Ö, Kumcağız H (2020) Covid-19 salgınında bireylerde algılanan stres düzeyi ve kaygı düzeyleri. Turkish Studies 15(4): 463-479.

Hapshy V, Aziz D, Kahar P, Khanna D, Johnson KE, Parmar MS (2021) Covid-19 and pregnancy: risk, symptoms, diagnosis, and treatment. SN Compr. Clin. Med. 3: 1477-1483.

Herawati D, Rosyada DF, Pratiwi RD, Wigati EN (2020) Family planning services by midwifery of private midwifery practice in yogyakarta during the pandemic period of covid-19. JIKM11(2):123-135.

Jolivet RR, Warren CE, Sripad P, Ateva E, Gausman J, Mitchell K, Hacker HP, Sacks E, Langer A (2020) Upholding rights under covid-19: the respectful maternity care charter. HHR 22(1): 391-394.

Kim DH (2020) Women's health during the covid19 pandemic. KJWHN 26(2):106-108.

Kuliukas L, Hauck Y, Sweet L, Vasilevski V, Homer C, Wynter K, Wilson W, Szabo R, Bradfield Z (2021) A cross sectional study of midwifery students' experiences of covid-19: uncertainty and expendability. NEP 51: 1-7.

Lazenby M, Chambers S, Cyhun D, Davidson P, Dithole K, Norman I, Tlou $\mathbf{S}$ (2020) Clinical nursing and midwifery education in the pandemic age. Int Nurs Rev 67(3): 323-325.

Liu H, Wang LL, Zhao SJ, Kwak-Kim J, Mor G, Liao AI (2020) Why are pregnant women susceptible to covid-19? an immunological viewpoint. J Reprod Immunol 139: 103-122. 
London V, McLaren R, Atallah F, Cepeda C, McCalla S, Fisher N, Stein JL, Haberman S, Minkoff H (2020) The relationship between status at presentation and outcomes among pregnant women with covid-19. Am J Perinatol 37(10): 991-994.

Mittal S, Singh T (2020) Gender-based violence during covid-19 pandemic: a mini-review. Frontiers in Global Women's Health, 1(4): 1-7.

Mokhtari F, Bahadoran P, Baghersad Z (2018) Effectiveness of postpartum homecare program as a new method on mothers' knowledge about the health of the mother and the infant. Iran J Nurs Midwifery Res 23(4): 316-321.

Monteblanco AD (2021) The covid-19 pandemic: a focusing event to promote communitymidwifery policies in the united states. Social Sciences\&Humanities 3: 1-6.

Murphy PA (2020) Midwifery in the time of covid19. JMWH 65(3): 299-300.

Nair M, Nelson-Piercy C, Knight M (2017) Indirect maternal deaths: uk and global perspectives. Obstetric Medicine 10(1):10-15.

Nasserie T, Hittle M, Goodman SN (2021) Assessment of the frequency and variety of persistent symptoms among patients with covid-19. JAMA Network Open 4(5): 1-19.

Nur AN, (2015) Doğum Korkusu: Literatür Değerlendirmesi. ODÜ Tıp Dergisi, 2: 161-165.

Ollivier R, Aston M, Price S, Sim M, Benoit B, Joy P, Iduye D, Nassaji NA (2021) Mental health \& parental concerns during covid-19: the experiences of new mothers amidst social isolatio. Midwifery, 94: 1-7.

Ostacoli L, Cosma S, Bevilacqua F, Berchialla $P$, Bovetti M, Carosso AR, Malandrone F, Carletto S, Benedetto C (2020) Psychosocial factors associated with postpartum psychological distress during the covid-19 pandemic: a cross-sectional study. BMC Pregnancy Childbirth, 20: 1-8. DOI: 10.1186/s12884020-03399-5.

Öztürk Çopur E, Can Z (2021) Salgın hastalıkların kadın sağlığına yansımaları. Haliç Üniv Sağ Bil Der 8792.

Pflugeisen BM, Carren C, Poore S, Carlile M, Schroeder $R$ (2016) Virtual visits: managing prenatal care with modern technology. MCN Am J Matern Child Nurs 41(1):24-30.

Renfrew MJ, Cheyne H, Craigc J, Duff E, Dykes F, Hunter B, Lavender T, Page L, Ross-Daviei M, Spibyj H, Downe S (2020) Sustaining quality midwifery care in a pandemic and beyond. Midwifery, 88: 1-8.

Rocca-Ihenacho L, Alonso C (2020) Where do women birth during a pandemic? changing perspectives on safe motherhood during the covid-19 pandemic. J Glob Sağlı Bilimi 2(1): 1-9.

Sayıner FD, Özerdoğan N (2009) Doğal Doğum. Maltepe Üniversitesi Hemşirelik Bilim ve Sanatı Dergisi, 2(3): 143-148.

Söğüt S, Dolu İ, Cangöl E (2021) The relationship between covid-19 knowledge levels and anxiety states of midwifery students during the outbreak: a cross-sectional web-based survey. Perspect Psychiatr Care 57(1): 246252.

Bilimsel Danışma Kurulu Çalışması (2020) T.C. Sağlık Bakanlığı Halk Sağlığı Genel Müdürlüğü Covid19 (Sars-Cov-2 Enfeksiyonu) Solunum Sistemi Hastalıklarının Yaygın Olduğu Dönemde Sağlık Kuruluşlarında Gebe Takibi, Ankara.

Türktan M, Berk N, Sucu M (2021) Covid-19'da sezaryende anestezi yönetimi. Cukurova Med J 46(2):844-847.

Uğraş Dikmen A, Kına HM, Özkan S, İlhan MN (2020) Covid-19 epidemiyolojisi: pandemiden ne öğrendik. J Biotechnol and Strategic Health Res 1(Özel Sayı):29-36.

Ulusal D (2021) Covid-19 pandemi döneminde kadın sağlık çalışanlarının yaşadıkları sorunların analizi. Uluslararası Sosyal Araștırmalar Dergisi, 14(77): 954-965.

Ünal B, Gülseren L (2020) Covid-19 pandemisinin görünmeyen yüzü: aile içi kadına yönelik şiddet. J Clin Psy 23(Ek 1): 89-94.

Velavan TP, Meyer CG (2020) The covid-19 epidemic. Trop Med Int Health 25(3): 278-280.

Zanardo V, Manghina V, Giliberti L, Vettore M, Severino L, Straface G (2020) Psychological impact of covid-19 quarantine measures in northeastern italy on mothers in the immediate postpartum period. FIGO 150(2): 184-188.

Zhang L, Jiang Y, Wei M, Cheng BH, Zhou XC, Li J, Tian JH, Dong L, Hu RH (2020) Analysis of the pregnancy outcomes in pregnant women with covid19 in hubei province. Zhonghua Fu Chan Ke Za Zhi 55(3): 166-171. 